\title{
Dyslipidemia and associated factors among women using hormonal contraceptives in Harar town, Eastern Ethiopia
}

\author{
Berhanu Sufa' ${ }^{1}$ Gemeda Abebe ${ }^{2}$ and Waqtola Cheneke ${ }^{2^{*}}$ (1)
}

\begin{abstract}
Objective: Dyslipidemia is abnormal amount of lipid in blood. Hormonal contraceptives affect lipid metabolism and can enhance the risk of vascular disease like atherosclerosis. In Harar, among contraceptive users, biochemical changes follow up is almost none and magnitude of dyslipidemia is not known. Therefore this study is designed to determine prevalence of dyslipidemia and its predisposing factors. Accordingly, cross-sectional study was conducted from April to June 2014 among hormonal contraceptive users from three health centers and one hospital. Sociodemographic data, anthropometric measurements, and blood biochemical tests were performed for every participant. Descriptive statistics and logistic regression analysis with 95\% confidence interval using SPSS was used.

Result: Totally 365 participants were included and the prevalence of dyslipidemia was 34.8\%. The mean levels \pm standard deviation of total cholesterol, low density lipoprotein (LDL), high density lipoprotein (HDL), the total cholesterol to HDL ratio, and triglyceride were $186 \pm 27 \mathrm{mg} / \mathrm{dl}, 121 \pm 31 \mathrm{mg} / \mathrm{dl}, 45.21 \pm 7.7 \mathrm{mg} / \mathrm{dl}, 4.44$, and $108 \pm 3.45 \mathrm{mg} / \mathrm{dl}$, respectively. Age, fasting blood sugar, drinking coffee twice and eating no vegetables 4 times/week were identified as predictors of dyslipidemia. In conclusion, hormonal contraceptive users of Harar have high rate of dyslipidemia. This result emphasizes the urgent need for a public health strategy for prevention, early detection, and treatment of dyslipidemia.
\end{abstract}

Keywords: Prevalence, Dyslipidemia, Hormonal contraceptives, Risk factor, Ethiopia

\section{Introduction}

Dyslipidemia is a condition that occurs because of abnormalities in the plasma lipids such as elevated plasma total cholesterol (TC), elevated low-density lipoprotein cholesterol (LDL-C), elevated triglycerides (TG) and reduced high-density lipoprotein cholesterol (HDL-C) levels, occurring singly or in combinations [1]. Together with other cardiovascular risk factors dyslipidemia may influence the progression of atherosclerosis [2]. Cardiovascular disease (CVD) is the leading cause of death in women and the third leading cause of death among women of reproductive age. During 2005 through 2008, 11\%

\footnotetext{
*Correspondence: waqtolachalt@yahoo.com

2 School of Medical Laboratory Sciences, Faculty of Health Sciences, Institute of Health, Jimma University, Jimma, Ethiopia

Full list of author information is available at the end of the article
}

of women aged 20 to 44 years had dyslipidemia [3, 4]. Hormonal contraceptives affect cardiac function, blood pressure (BP), fat and carbohydrate metabolism [5]. The resultant effect of contraceptive hormones on lipid metabolism depends on the type and dose of the compounds, the route of administration, and the duration of treatment [6]. Prolonged use of hormonal contraceptives by females during their reproductive age can induce metabolic changes that may contribute to an increased risk of coronary heart [7]. It is now generally accepted that both elevated levels of non-HDL-C and low HDL-C concentrations may promote the development of atherosclerosis [8]. As the resultant effect of combined oral contraceptives (COC) on the formation of dyslipidemia depends on different factors and dyslipidemia promotes development of atherosclerosis, determining magnitude of dyslipidemia and other cardiovascular risk factors among 
women using hormonal contraceptive helps to aware health care workers to use options for its management. However, there is no study for determination of dyslipidemia and cardiovascular risk factors for women using hormonal contraceptives in all health facilities in Harar town. Hence, the objective of this study is to determine the prevalence of dyslipidemia and associated factor among women using hormonal contraceptives.

\section{Main text \\ Methods \\ Study setting and participants}

A cross sectional study was conducted from April to June, 2014 in Harar Eastern Ethiopia, which was selected randomly and is $515 \mathrm{~km}$ away from Addis Ababa. Sample size was determined using single population proportion formula and then corrected by finite population correction formula to include a total of 365 hormonal contraceptive users having complete recorded data, satisfied the inclusion criteria and volunteer to participate in the study. To include participants randomly from the town, we stratified the town into three areas and randomly selected at least 1 public health institution from every area. Participants were included consecutively from 3 health facilities ( 2 health centers and 1 hospital) in the town till the determined sample size was achieved. The 3 facilities were selected randomly. The 365 sample size was divided proportionately among the 2 health centers and the 1 hospital as 1:1:1.65 ratios, respectively. Hormonal contraceptive users with the current history of pregnancy; those who have history of hypertension, diabetes, HIV/AIDS, mental disorders and those who were on lipid lowering medications were excluded from the study.

\section{Data collection and laboratory testing}

Socio demographic and clinical data were collected using structured questionnaire and checklist. Each consented participants were informed about the importance of obtaining overnight fasting blood specimen and advised to come early in the morning by the next day; then about $10 \mathrm{ml}$ of venous blood was collected from each into clean serum separator test tubes and allowed to clot for $30 \mathrm{~min}$. After retracting the clot the samples were centrifuged at 3000 rpm's for $10 \mathrm{~min}$ and $5 \mathrm{ml}$ pure serum samples were transferred to nunc tubes and analyzed for fasting blood sugar (FBS), TC, TG, and LDL-C using Mindray BS-120 chemistry analyzer. HDL-C was calculated in serum specimens having a TG value $<400 \mathrm{mg} / \mathrm{dl}$ by reverse method using Friedewald formula.

Standard operating procedures and manufacturer instructions were strictly followed throughout the procedures. Quality control run was undertaken for all laboratory tests in this study.

\section{Statistical analysis}

Data was edited, cleaned, coded and entered using Epidata and then exported to SPSS for analysis. Mean, standard deviation and frequency of quantitative variables were calculated. Bivariate and multivariate logistic regression analysis was calculated with $95 \%$ confidence interval $(\mathrm{CI})$ to evaluate the possible association of the variables and $p$-value of less than 0.05 was considered as statistically significant.

\section{Results}

\section{Demographic and anthropometric data}

A total of 365 consented women were enrolled in this study with overall response rate of $100 \%$. The mean plus or minus standard deviation $( \pm S D)$ age of the participants was 30.1 ( \pm 6.7 ) years. Majority, $163(44.7 \%)$, of the participants were $20-29$ years old. The mean height and weight of the subjects were $161( \pm 0.06) \mathrm{cm}$ and 57.9 $( \pm 6.8) \mathrm{kg}$, respectively. Majority, 187 (51.2\%), of the participants were Muslim by religion and Oromo by ethnicity [162 (44.4\%)]. Educationally, majority of them, 206 (56.4\%), attended above secondary school; occupationally 157 (43\%) of them were housewives and 307 (84.1\%) were married. The mean monthly income of the family was 1786.6 Ethiopian birr (ETB) (Table 1).

\section{Clinical and laboratory data}

The mean $( \pm S D)$ levels of TC, LDL-C, HDL-C, TG, and the TC/HDL-C ratio of the study subjects were 186 $( \pm 27) \mathrm{mg} / \mathrm{dl}, 121( \pm 31) \mathrm{mg} / \mathrm{dl}, 45.21( \pm 7.7) \mathrm{mg} / \mathrm{dl}, 108$ $( \pm 3.45) \mathrm{mg} / \mathrm{dl}$, and 4.44 , respectively. The age-adjusted mean $( \pm S D)$ levels of the lipid profiles are presented in tables (Additional file 1: Table S1). Moreover their mean $( \pm \mathrm{SD})$ in comparison with types and duration of contraceptives used are presented in tables (Additional file 2: Table S2 and Additional file 3: Table S3).

A total of $30(8.2 \%)$ participants had a FBS $>126 \mathrm{mg} /$ $\mathrm{dl}$ and $73(20 \%)$ had body mass index (BMI) $>25 \mathrm{~kg} / \mathrm{m}^{2}$. Only $12(3.3 \%)$ participants had systolic blood pressure $(\mathrm{SBP})>140 \mathrm{mmHg}$ and 23 (6.3\%) had diastolic blood pressure (DBP) $>90 \mathrm{mmHg}$. Moreover, $94(25.8 \%)$ had a waist-to-hip ratio $>0.85 ; 16(4.4 \%), 21(5.8 \%)$, and $11(3 \%)$ had family history of hypertension, of diabetes mellitus and of obesity, respectively. Likewise, 203 (55.6\%) drink coffee; of which 163 (44.7\%) drink at least once a day and 40 (11\%) drink more than twice a day. Similarly 186 (51\%) make physical exercise for at least $30 \mathrm{~min}$ a day of which $176(48.2 \%)$ perform $<3$ times a week and $10(2.7 \%)>4$ times a week. Furthermore, 17 (4.4\%) participants drink alcohol and $69(18.9 \%)$ chew khat at least once a week (Table 2). 
Table 1 Associations of socio-demographic factors with dyslipidemia women using hormonal contraceptives by using binary logistic regression in Harar town, April-June; 2014

\begin{tabular}{|c|c|c|c|c|c|c|}
\hline & \multirow[t]{2}{*}{ Characteristics } & \multicolumn{3}{|c|}{ Dyslipidemia } & \multirow[t]{2}{*}{ COR $(95 \% \mathrm{Cl})$} & \multirow[t]{2}{*}{ p-value } \\
\hline & & No (N/\%) & Yes (N/\%) & Total & & \\
\hline \multirow[t]{4}{*}{ Age } & $<20$ & $12(92.3)$ & $1(7.7)$ & 13 & 1 & \\
\hline & $20-29$ & $73(47.7)$ & $80(52.3)$ & 163 & $2.60(0.325,20.769)$ & 0.368 \\
\hline & $30-39$ & $134(82.2)$ & $29(17.8)$ & 153 & $13.15(1.669,103.647)$ & 0.014 \\
\hline & $\geq 40$ & $19(52.8)$ & $17(47.2)$ & 36 & $10.74(1.260,91.47)$ & 0.030 \\
\hline \multirow[t]{3}{*}{ Marital status } & Widowed & $2(66.7)$ & $1(33.3)$ & 3 & 1 & \\
\hline & Married & $199(64.8)$ & $108(35.2)$ & 307 & $1.085(0.097,12.11)$ & 0.947 \\
\hline & Single/divorced & $37(67.3)$ & $18(32.7)$ & 55 & $1.29(0.101,16.2)$ & 0.64 \\
\hline \multirow[t]{4}{*}{ Ethnicity } & Gurage & $22(62.9)$ & $13(37.1)$ & 35 & 1 & \\
\hline & Oromo & $104(64.2)$ & $58(35.8)$ & 162 & $0.944(0.443,2.012)$ & 0.88 \\
\hline & Amhara & 68 (71.6) & $27(28.4)$ & 95 & $0.0 .67(0.297,1.52)$ & 0.341 \\
\hline & Harari & $44(60.3)$ & $29(39.7)$ & 73 & $1.115(0.49,2.56)$ & 0.191 \\
\hline \multirow[t]{4}{*}{ Education } & Illiterate & $52(66.7)$ & $25(33.3)$ & 77 & 1 & \\
\hline & Primary school & $54(66.7)$ & $27(33.3)$ & 81 & $1.000(0.517,1.93)$ & 1.000 \\
\hline & Secondary school & $74(72.5)$ & $28(27.5)$ & 102 & $0.757(0.39,1.44)$ & 0.394 \\
\hline & $\geq$ Higher education & $58(55.8)$ & $46(44.2)$ & 104 & $1.59(0.86,2.92)$ & 0.797 \\
\hline \multirow[t]{3}{*}{ Religion } & Orthodox & $85(67.5)$ & $41(32.5)$ & 126 & 1 & \\
\hline & Muslim & 119 (63.6) & $68(36.4)$ & 187 & $1.185(0.74,1.91)$ & 0.490 \\
\hline & Protestant & $34(65.4)$ & $18(34.6)$ & 52 & $1.10(0.56,2.17)$ & 0.789 \\
\hline \multirow[t]{2}{*}{ Income } & $\leq 1500$ & $135(69.2)$ & $60(30.8)$ & 195 & 1 & \\
\hline & $>1500$ & $103(60.6)$ & $67(39.4)$ & 170 & $1.464(0.95,2.256)$ & 0.084 \\
\hline \multirow[t]{4}{*}{ Occupation } & House wife & $105(66.9)$ & $52(33.1)$ & 157 & 1 & \\
\hline & Merchant & $45(67.2)$ & $22(32.8)$ & 67 & $0.987(0.537,1.814)$ & 0.967 \\
\hline & Employed & $85(61.6)$ & $53(38.4)$ & 138 & $1.26(0.78,2.030)$ & 0.345 \\
\hline & Others & $3(100)$ & $0(0)$ & 3 & 0.000 & 0.999 \\
\hline
\end{tabular}

COR crude odds ratio

\section{Prevalence of dyslipidemia}

Dyslipidemia or abnormal values of TC, TG, LDL, HDL and TC/HDL ratio were identified, with overall prevalence of $34.8 \%$ (Additional file 4: Figure S1). Sociodemographic variables such as age, occupation, income, religion, marital status and educational status were taken as study variables. The presence of dyslipidemia was statistically different among age categories. However, there was no difference among religion, ethnicity, marital status, educational status and occupation (Table 1). Additionally, the presence of dyslipidemia was assessed based on BP, BMI, waist circumference, waist-to-hip ratio (WHR), FBS, life style, feeding habits, family history of selected medical condition, parity and type and duration of hormonal contraceptives. Women with dyslipidemia were 10 times likely to have $\mathrm{SBP}>140 \mathrm{mmHg}$ (Odds ratio $(\mathrm{OR})=10.085 ; 95 \% \mathrm{CI} 2.175-46.78, \mathrm{p}=0.003)$ and 8 times likely to have $\mathrm{DBP}>90 \mathrm{mmHg}(\mathrm{OR}=7.695 ; 95 \%$ CI $2.78-21.27, \mathrm{p}=0.000$ ) as compared to their counterparts. However, there was no difference in dyslipidemia between types of contraceptives, drinking alcohol and cigarette smoking (Table 2). The proportion of women having dyslipidemia in comparison with the type and duration of use of contraceptive are presented in table (Additional file 5: Table S4). The percentage of dyslipidemia in respect to individual biochemical parameters of the lipid profiles are displayed in table (Additional file 6: Table S5).

\section{Predictors of dyslipidemia}

The significant predictors of dyslipidemia in this study were age, FBS, not eating vegetables and drinking coffee twice. Women who do not eat vegetables were about 3 times more likely to develop dyslipidemia (adjusted odds ratio $(\mathrm{AOR})=3.14 ; 95 \%$ CI $1.27-7.77, \mathrm{p}=0.013$ ) and those who drink coffee more than 2 times per day were about 5 times more likely to develop dyslipidemia $(\mathrm{AOR}=4.810 ; 95 \%$ CI 1.23-18.76, $\mathrm{p}=0.024)$ (Table 3$)$.

\section{Discussion}

Dyslipidemia is a common public health problem in developing countries, the prevalence of which is rising 
Table 2 Associations of cardiovascular and life style factors with dyslipidemia among contraceptive user women by using binary logistic regression in Harar town, 2014

\begin{tabular}{|c|c|c|c|c|c|c|}
\hline & \multirow[t]{2}{*}{ Variables } & \multicolumn{2}{|c|}{ Dyslipidemia } & \multirow[b]{2}{*}{ Total } & \multirow[t]{2}{*}{ COR $(95 \% \mathrm{CI})$} & \multirow[t]{2}{*}{ p-value } \\
\hline & & No (N/\%) & Yes (N/\%) & & & \\
\hline \multirow[t]{2}{*}{ SBP (mmHg) } & $\leq 139$ & $236(66.9)$ & $117(33.1)$ & 353 & 1 & \\
\hline & $\geq 140$ & $2(16.7)$ & $10(83.3)$ & 12 & $10.085(2.175,46.78)$ & 0.003 \\
\hline \multirow{2}{*}{$\begin{array}{l}\text { Diastolic blood pressure } \\
(\mathrm{mmHg})\end{array}$} & $\leq 89$ & $233(68.1)$ & $109(31.9)$ & 342 & 1 & \\
\hline & $\geq 90$ & $5(21.7)$ & $18(78.3)$ & 23 & $7.695(2.78,21.27)$ & 0.000 \\
\hline \multirow[t]{4}{*}{ Body mass index $\left(\mathrm{kg} / \mathrm{m}^{2}\right)$} & $<18.50$ & $8(88.9)$ & $1(11.1)$ & 9 & 1 & \\
\hline & $18.50-24.9$ & $217(76.7)$ & $66(23.3)$ & 283 & $2.433(0.299,19.811)$ & 0.406 \\
\hline & $25-29.99$ & $13(18.6)$ & $57(81.4)$ & 70 & $35.077(4.028,305.49)$ & 0.000 \\
\hline & $\geq 30$ & $0(0)$ & $3(100)$ & 3 & 0 & 0.999 \\
\hline \multirow[t]{2}{*}{ Waist to hip ratio } & $\leq 0.85$ & $198(73.1)$ & $73(26.9)$ & 271 & 1 & \\
\hline & $>0.85$ & $40(42.6)$ & $54(57.4)$ & 94 & $3.662(2.245,5.97)$ & 0.000 \\
\hline \multirow[t]{3}{*}{ Fasting blood sugar (mg/dl) } & $<110$ & $222(88.1)$ & $30(11.9)$ & 252 & 1 & \\
\hline & $110-125$ & $13(15.7)$ & $70(84.3)$ & 83 & $39.85(19.706,80.57)$ & 0.000 \\
\hline & $\geq 126$ & $3(10)$ & $27(90)$ & 30 & $66.6(19.038,232.98)$ & 0.000 \\
\hline \multirow{2}{*}{$\begin{array}{l}\text { Family history of diabetes } \\
\text { mellitus }\end{array}$} & No & $233(67.7)$ & $111(32.3)$ & 344 & 1 & \\
\hline & Yes & $5(23.8)$ & $16(76.2)$ & 21 & $6.717(2.400,18.802)$ & 0.000 \\
\hline \multirow[t]{2}{*}{ Family history of hypertension } & No & $234(67)$ & $115(33.0)$ & 349 & 1 & \\
\hline & Yes & $4(25)$ & $12(75)$ & 16 & $6.104(1.926,19.344)$ & 0.002 \\
\hline \multirow[t]{2}{*}{ Family history of obesity } & No & $234(66.1)$ & $120(33.9)$ & 354 & 1 & \\
\hline & Yes & $4(36.4)$ & $7(63.6)$ & 11 & $0.293(0.084,1.021)$ & 0.054 \\
\hline \multirow[t]{3}{*}{ Coffee } & No & $119(73.5)$ & $43(26.5)$ & 162 & 1 & \\
\hline & $<2$ times/day & $108(66.3)$ & $55(33.7)$ & 163 & $1.409(0.875,2.270)$ & 0.158 \\
\hline & $\geq 2$ times/day & $11(27.5)$ & $29(72.5)$ & 40 & $7.296(3.355,15.86)$ & 0.000 \\
\hline \multirow[t]{3}{*}{ Physical exercise } & $>3$ times/week & $8(80)$ & $2(20)$ & 10 & 1 & \\
\hline & $\leq 3$ times/week & $147(83.5)$ & $29(16.5)$ & 176 & $0.171(0.104,0.280)$ & 0.057 \\
\hline & No & $83(46.4)$ & $96(53.6)$ & 179 & $0.216(0.045,1.046)$ & 0.000 \\
\hline \multirow[t]{2}{*}{ Smoking } & No & $234(65)$ & $126(35)$ & 360 & 1 & \\
\hline & Yes & $4(80)$ & $1(20)$ & 5 & $2.154(0.238,19.477)$ & 0.495 \\
\hline \multirow[t]{2}{*}{ Alcohol use } & No & $224(64.4)$ & $124(35.6)$ & 348 & 1 & \\
\hline & Yes & $14(82.4)$ & $3(17.6)$ & 17 & $2.583(0.728,9.163)$ & 0.142 \\
\hline \multirow[t]{2}{*}{ Chew khat } & No & $197(66.6)$ & $99(33.4)$ & 296 & 1 & \\
\hline & Yes & $41(59.4)$ & $28(40.6)$ & 69 & $0.736(0.430,1.260)$ & 0.264 \\
\hline \multirow[t]{5}{*}{ Parity } & Nulliparous & $40(83.3)$ & $8(16.7)$ & 48 & 1 & \\
\hline & 1 & $73(76)$ & $23(24)$ & 96 & $1.575(0.646,3.844)$ & 0.318 \\
\hline & 2 & $57(53.3)$ & $50(46.7)$ & 107 & $4.386(1.877,10.25)$ & 0.001 \\
\hline & 3 & $36(63.2)$ & $21(36.8)$ & 57 & $2.917(1.150,7.396)$ & 0.024 \\
\hline & 4 & $32(56.1)$ & $25(43.9)$ & 57 & $3.906(1.554,9.821)$ & 0.004 \\
\hline \multirow{4}{*}{$\begin{array}{l}\text { Types of hormonal contracep- } \\
\text { tives }\end{array}$} & Jedalle/norplant & $14(60.9)$ & $9(39.1)$ & 23 & 1 & \\
\hline & Injectable & $127(59.9)$ & $85(40.1)$ & 212 & $1.041(0.431,2.513)$ & 0.429 \\
\hline & OCP & $38(71.7)$ & $15(28.3)$ & 53 & $0.614(0.219,1.718)$ & 0.353 \\
\hline & Implanon & $59(76.6)$ & $18(23.4)$ & 77 & $0.475(0.176,1.277)$ & 0.140 \\
\hline \multirow[t]{4}{*}{ Duration (in months) } & $6-18$ & $127(75.6)$ & $41(24.4)$ & 168 & 1 & \\
\hline & $18-30$ & $63(71.6)$ & $25(28.4)$ & 88 & $1.229(0.687,2.199)$ & 0.487 \\
\hline & $30-42$ & $31(56.4)$ & $24(43.6)$ & 55 & $2.398(1.266,4.542)$ & 0.007 \\
\hline & $>42$ & $17(31.5)$ & $37(68.5)$ & 54 & $6.742(3.437,13.22)$ & 0.000 \\
\hline Eat meat/week & No & $37(78.7)$ & $10(21.3)$ & 47 & 1 & \\
\hline & $\leq 4$ times & $196(64.9)$ & $106(35.1)$ & 302 & $2.001(0.957,4.183)$ & 0.065 \\
\hline & $>4$ times & $5(31.2)$ & $11(68.8)$ & 16 & $8.140(2.293,28.901)$ & 0.001 \\
\hline
\end{tabular}


Table 2 (continued)

\begin{tabular}{|c|c|c|c|c|c|c|}
\hline & \multirow[t]{2}{*}{ Variables } & \multicolumn{2}{|c|}{ Dyslipidemia } & \multirow[b]{2}{*}{ Total } & \multirow[t]{2}{*}{ COR $(95 \% \mathrm{Cl})$} & \multirow[t]{2}{*}{$p$-value } \\
\hline & & No (N/\%) & Yes (N/\%) & & & \\
\hline \multirow[t]{3}{*}{ Eat veg./week } & $>4$ times/week & $70(71.4)$ & $28(28.6)$ & 98 & 1 & \\
\hline & $\leq 4$ times & $165(63.2)$ & $96(36.8)$ & 261 & $2.500(0.476,13.138)$ & 0.250 \\
\hline & No & $3(50)$ & $3(50)$ & 6 & $1.455(0.878,2.411)$ & 0.126 \\
\hline \multirow[t]{3}{*}{ Use milk } & No & $56(72.7)$ & $21(27.3)$ & 77 & 1 & \\
\hline & $\leq 4$ times & $159(71)$ & $65(29)$ & 224 & $0.090(0.611,1.944)$ & 0.77 \\
\hline & $>4$ times & $23(35.9)$ & $41(64.1)$ & 64 & $4.754(2.32,9.724)$ & 0.000 \\
\hline
\end{tabular}

$\mathrm{mmHg}$ millimeter mercury, $\mathrm{kg} / \mathrm{m}^{2}$ kilogram per meter square, $\mathrm{mg} / \mathrm{dl}$ milligram per deciliter

steadily [9]. To the best of our knowledge this study is the first to examine prevalence of dyslipidemia and associated factors in Ethiopia. In this study the prevalence of dyslipidemia was found to be $34.8 \%$ which is lower than finding in Iran (63.4\%) [9].

The predictors of dyslipidemia were age $>30$ years, FBS $>110 \mathrm{mg} / \mathrm{dl}$, coffee drinking $>2$ times a day and not eating vegetables. The result for not eating vegetables agrees with the study conducted in Framingham [10] but literature on the effect of coffee on serum lipids in women using hormonal contraceptive is limited.

The mean levels of lipid profile are different from finding in Iraq [11]. This difference might be due to the socio-demographic and socioeconomic status of the study subjects.

The prevalence of hypercholesterolemia ( $\mathrm{TC} \geq 200 \mathrm{mg} / \mathrm{dl}$ ) was $33.7 \%$ and the mean $\mathrm{TC}$ level $(186 \pm 27 \mathrm{mg} / \mathrm{dl})$ of this study is comparable with that in Brazil [12] and Germany [13] but lower than Bangladesh, Dhaka [14] and higher than Iraq [11]. Significantly increased TC might be due to differences in socioeconomic, life style, methodology and duration and type of contraceptives.

The prevalence of hyperlipidemia (LDL-C $\geq 130 \mathrm{mg} / \mathrm{dl}$ ) is found to be $34.8 \%$ and the mean LDL-C $(121 \pm 31 \mathrm{mg} /$ $\mathrm{dl}$ ) is lower than study in Bangladesh, Dhaka [14], but higher than Brazil [12], Germany [13] and Iraq [11]. This variation might be due to differential distribution in risk factors.

The prevalence of hypolipidemia (HDL-C $<40 \mathrm{mg}$ / dl) was $28.2 \%$. The alteration in the reference value, as to the new recommendations [15] made comparison difficult with the previous studies. The mean HDL-C $(45.21 \pm 7.7 \mathrm{mg} / \mathrm{dl})$ is lower compared with study in Brazil [12], Germany [13] and Iraq [11] but higher than Bangladesh, Dhaka [14].

The prevalence of hypertriglyceridemia was found to be $17.0 \%$ which is comparable with studies in developing countries including Africa where its level ranges from 15 to $30 \%$ [16]. The mean TG $(107 \pm 34 \mathrm{mg} / \mathrm{dl})$ is comparable with finding in Bangladesh, Dhaka [14] but, lower than Basra, Iraq [11] and higher than Pakistan [7]. The decreased prevalence of hypertriglyceridemia in this study might be related to hormonal contraceptive induced increase in clearance of TG rather than synthesis and might be because of fasting.

The mean SBP $(119.85 \pm 9.5 \mathrm{mmHg})$ and DBP $(77.96 \pm 6.8 \mathrm{mmHg})$ are consistent with the study in Germany [13] but SBP is different from Basra, Iraq [11]. This variation might be due to difference of socio-demographic factors, genetic predisposition, dietary factors, and lack of physical activity.

The level of TC, TG and LDL-C has increased with duration of contraceptive intake but, HDL-C level is significantly decreased. This agrees with a study in Nigeria [17] but the LDL-C level is different from Basra; Iraq [11] in which it was decreased with duration of contraceptive use. Significant decrease $(\mathrm{p}<0.05)$ of HDL-cholesterol was observed within the duration of different types of hormonal contraceptives [18-21].

Dyslipidemia was higher among groups with high educational level. This might be resulted from higher income, poor working conditions and poor nutritional habits.

The prevalence of dyslipidemia was significantly higher among employed 53 (38.4\%) and house wives 52 (33.1\%) which might be due to poor physical activity. The odds ratio for dyslipidemia is significantly greater in subjects with a family history of obesity, diabetes and hypertension. Cigarette smoking has no significant association with dyslipidemia which is similar with study conducted in Germany [13].

The prevalence of dyslipidemia has increased with parity, however; there was a fluctuating pattern in HDL-C level in between consecutive pregnancies which is similar to studies according to Mankuta et al. [21].

\section{Conclusion}

This study revealed that dyslipidemia is high among the study subjects and age, FBS, drinking coffee twice and not eating vegetables were found to be the independent 
Table 3 Multivariate analysis of independent risk factors for dyslipidemia in women using contraceptive hormones; in Harar town, April-June 2014

\begin{tabular}{|c|c|c|c|c|c|c|}
\hline & \multirow[t]{2}{*}{ Variables } & \multicolumn{3}{|c|}{ Dyslipidemia } & \multirow[t]{2}{*}{ AOR $(95 \% \mathrm{Cl})$} & \multirow[t]{2}{*}{$p$-value } \\
\hline & & No (N/\%) & Yes (N/\%) & Total & & \\
\hline \multirow[t]{4}{*}{ Age (years) } & $<20$ & $12(92.3)$ & $1(7.7)$ & 13 & 1 & \\
\hline & $20-29$ & $73(47.7)$ & $80(52.8)$ & 153 & $33.43(1.23,45.2)$ & 0.065 \\
\hline & $30-39$ & $134(82.2)$ & $29(17.8)$ & 163 & $44.45(1.104,18)$ & 0.044 \\
\hline & $\geq 40$ & $19(52.8)$ & $17(47.2)$ & 36 & $28.05(1.44,30.9)$ & 0.098 \\
\hline \multirow[t]{3}{*}{ FBS (mg/dl) } & $\leq 110$ & $222(88.1)$ & $30(11.9)$ & 252 & 1 & \\
\hline & $110-126$ & $13(15.7)$ & $70(84.3)$ & 83 & $35.95(14.35,89.90)$ & 0.000 \\
\hline & $>126$ & $3(10)$ & $27(90)$ & 30 & $35.75(8.66,147.50)$ & 0.000 \\
\hline \multirow[t]{3}{*}{ Eat vegetables } & $>4$ times/week & $70(71.4)$ & $28(28.6)$ & 98 & 1 & \\
\hline & No & $3(50)$ & $3(50)$ & 6 & $3.14(1.27,7.77)$ & 0.013 \\
\hline & $\leq 4$ times & $196(64.9)$ & $106(35.1)$ & 302 & $2.09(0.87,5.23)$ & 0.070 \\
\hline \multirow[t]{2}{*}{ Drink coffee } & No & $119(73.5)$ & $43(26.5)$ & 162 & 1 & \\
\hline & $\geq 2$ times/day & $11(27.5)$ & $29(72.5)$ & 40 & $4.810(1.23,18.76)$ & 0.024 \\
\hline
\end{tabular}

$A O R$ adjusted odds ratio, $F B S$ fasting blood sugar, $\mathrm{mg} / \mathrm{dl}$ milligram per deciliter, $\mathrm{Cl}$ confidence interval

predictors of dyslipidemia. The finding of this study indicates the urgent need for public health strategy to prevent, detect, and treat the dyslipidemia. Public health measures should continue to emphasize on the importance of healthy feeding habits and screening for different metabolic disorders as well as provision and monitoring of the quality of family planning services. Moreover large scale longitudinal study is needed to determine the effect of hormonal contraceptives on serum lipid and lipoprotein levels. Thus, this study can be used as baseline information for further studies related to effect of hormonal contraceptives on serum lipid levels.

\section{Limitations}

As this study is cross sectional type, the long term effect could not be synthesized from the data. This study is also facility based but it would have been better if it was community based and the sample size was randomly selected from the community.

\section{Additional files}

Additional file 1: Table S1. The age-adjusted mean \pm SD values of plasma lipids and TC/HDL-C ratio in women using hormonal contraceptives in Harar by age groups, 2014.

Additional file 2: Table S2. The mean \pm SD values of plasma lipids and $\mathrm{TC} / \mathrm{HDL}-\mathrm{C}$ ratio in women using hormonal contraceptives in Harar by types of contraceptive use, 2014.

Additional file 3: Table S3. The mean \pm SD values of plasma lipids and TC/HDL-C ratio in women using hormonal contraceptives in Harar by duration of contraceptive use in months, 2014.

Additional file 4: Figure S1. Prevalence of dyslipidemia among women using hormonal contraceptives in Harar town, 2014.
Additional file 5: Table S4. Dyslipidemia versus types and duration of hormonal contraceptive users in Harar town, April-June; 2014.

Additional file 6: Table S5. Distribution of dyslipidemia with respect to individual biochemical parameters among women using hormonal contraceptives in Harar town; April-June; 2014.

\section{Abbreviations}

AIDS: acquired immunodeficiency syndrome; AOR: adjusted odds ratio; BMl: body mass index; BP: blood pressure; Cl: confidence interval; $\mathrm{COC}$ : combined oral contraceptive; CVD: cardiovascular disease; DBP: diastolic blood pressure; HDL: high density lipoprotein; HIV: human immunodeficiency virus; LDL: low density lipoprotein; $\mathrm{mg} / \mathrm{dl}$ : milligram per deciliter; $\mathrm{mmHg}$ : millimeter mercury; OR: odds ratio; SBP: systolic blood pressure; SD: standard deviation; TC: total cholesterol; TC/HDL: total cholesterol: high density lipoprotein; TG: Triglyceride; WHR: waist to hip ratio.

\section{Authors' contributions}

$\mathrm{BS}$, WC and GA conceived the study, participated in the design, data analysis and interpretation of the result. BS involved in data acquisition, laboratory work and drafted the manuscript. WC and GA critically reviewed the manuscript. All authors read and approved the final manuscript.

\section{Author details}

${ }^{1}$ Department of Medical Laboratory Science, Harar Health Science College, Harar, Ethiopia. ${ }^{2}$ School of Medical Laboratory Sciences, Faculty of Health Sciences, Institute of Health, Jimma University, Jimma, Ethiopia.

\section{Acknowledgements}

We would like to thank data collectors and study subjects.

\section{Competing interests}

The authors declare that they have no competing interests.

\section{Availability of data and materials}

The datasets used and/or analyzed during the current study are available from the corresponding author on reasonable request.

\section{Consent for publication}

This manuscript does not include details, images, or videos relating to study participants. Thus written consent for the publication is not applicable for it. 


\section{Ethics approval and consent to participate}

Ethical clearance was obtained from Jimma university health sciences ethical review board. Study participants have consented verbally to participate in the study. We used verbal rather than written consent to become consistent among the participants as their educational status could be different. Moreover, individuals who were found to have abnormal results including dyslipidemia were sent to the health care workers for further management of the problem.

\section{Funding}

This study is funded by Jimma University.

\section{Publisher's Note}

Springer Nature remains neutral with regard to jurisdictional claims in published maps and institutional affiliations.

Received: 20 September 2018 Accepted: 22 February 2019

Published online: 04 March 2019

\section{References}

1. Oguejiofor OC, Onwukwe $\mathrm{CH}$, Odenigbo CU. Dyslipidemia in Nigeria: prevalence and pattern. Ann Afr Med. 2012;11:197-202.

2. Reiner Z, Catapano AL, De Backer G, et al. ESC/EAS Guidelines for the management of dyslipidaemias: The Task Force for the management of dyslipidaemias of the European Society of Cardiology (ESC) and the European Atherosclerosis Society (EAS). Eur Heart J. 2011;32(14):1769-818.

3. CDC. National Center for Health Statistics. http://www.cdc.gov/nchs/hdi. htm. Accessed 26 Feb 2016.

4. Heron MP, Hoyert DL, Murphy SL, Xu JQ, Kochanek KD, Tejada-Vera B. Deaths: final data for 2006. National vital statistics reports, vol 57, no 14. Hyattsville: National Center for Health Statistics; 2009

5. Wiegratz I, Thaler CJ. Hormonal contraception-what kind, when, and for whom? Deutsches Ärzteblatt Int. 2011;108(28-29):495-506.

6. Mendelsohn ME, Karas $\mathrm{RH}$. The protective effects of estrogen on the cardiovascular system. N Engl J Med. 1999;340:1801-11.

7. Jamil S, Siddiq A. Comparison of CVD risk associated with the long term use of contraceptives in young females. J Appl Pharm Sci. 2012;2(11):062-6.

8. Bittner $\mathrm{V}$. Perspectives on dyslipidemia and coronary heart disease in women. J Am Coll Cardiol. 2005:46(9):1628-35.
9. Delavar MA, Lye MS, Hassan STBS, Khor GL, Hanachi P. Physical activity, nutrition, and dyslipidemia in middle-aged women. Iran J Public Health. 2011:40(4):89-98.

10. Djoussé L, Arnett DK, Coon H, Province MA, Moore LL, Ellison RC. Fruit and vegetable consumption and LDL cholesterol: the National Heart, Lung, and Blood Institute Family Heart Study. Am J Clin Nutr. 2004;79(2):213-7.

11. Abdel-Barry JA, Flafl MS, Al-Namaa LM, Hassan NA. Lipoprotein changes in women taking low-dose combined oral contraceptive pills: a crosssectional study in Basra, Iraq. East Mediterr Health J. 2011;17(9):684-8.

12. Machado RB, de Melo NR, Maia H Jr, Cruz AM. Effect of a continuous regimen of contraceptive combination of ethinylestradiol and drospirenone on lipid, carbohydrate and coagulation profiles. Contraception. 2010;81(2):102-6.

13. Du Y, Rosner BM, Knopf H, Schwarz S, Doren M, Scheidt-Nave C. Hormonal contraceptive use among adolescent girls in Germany in relation to health behavior and biological cardiovascular risk factors. J Adolesc Health. 2011;48:331-7.

14. Yesmin F, Sarkar CR, Zahid AZ, Ahmed A, Hossain MS. Lipid profile in oral contraceptives user women. Dinajpur Med Col J. 2013;6(1):54-7.

15. Clinical practice guideline for the management of dyslipidemia. Department of Veterans Affairs Department of Defense. Updated version 2; 2006. https://www.healthquality.va.gov/guidelines/CD/lipids/lip05 _950_final2.pdf. Accessed 26 Feb 2016.

16. Brien SE, Ronksley PE, Turner BJ, Mukamal KJ, Ghali WA. Effect of alcohol consumption on biological markers associated with risk of coronary heart disease: systematic review and meta-analysis of interventional studies. BMJ. 2011;342:d636.

17. Emokpae MA, Uadia PO, Osadolor HB. Effect of duration of use of hormonal contraceptive pills on total lipid and lipoproteins in Nigerian women. Int J Pharm Biol Sci. 2010;1(3). http://citeseerx.ist.psu.edu/viewdoc/downl oad?doi $=10.1 \cdot 1.178 .1876 \&$ rep $=$ rep $1 \&$ type $=$ pdf

18. Nessa A, Latif SA, Uddin MM, Hussain MA. Serum HDL-cholesterol in women using low dose oral contraceptives. MMJ. 2007;16(2 Suppl):S3-6.

19. Sadiqa S, Qureshi MA. Effects of hormonal contraception on plasma lipid and lipoprotein cholesterol concentrations. J Coll Physicians Surg Pak. 2002:12:593-8

20. Szlendak-Sauer K, Radowicki S, Skórzewska K. The impact of a new low dose oral contraceptive containing drospirenone on lipid profile, carbohydrate metabolism and hepatic function. Ginekol Pol. 2009;80(2):99-102.

21. Mankuta D, Elami-Suzin M, Elhayani A, Vinker S. Lipid profile in consecutive pregnancies. Lipids Health Dis. 2010;9:58.
Ready to submit your research? Choose BMC and benefit from:

- fast, convenient online submission

- thorough peer review by experienced researchers in your field

- rapid publication on acceptance

- support for research data, including large and complex data types

- gold Open Access which fosters wider collaboration and increased citations

- maximum visibility for your research: over $100 \mathrm{M}$ website views per year

At $\mathrm{BMC}$, research is always in progress.

Learn more biomedcentral.com/submissions 